\title{
Pathogenesis of Apical Periodontitis: a Literature Review
}

\author{
Indre Graunaite ${ }^{1}$, Greta Lodiene ${ }^{1}$, Vita Maciulskiene ${ }^{1}$ \\ 'Department of Dental and Oral Pathology, Faculty of Odontology, Lithuanian University of Health Sciences, Lithuania.
}

\author{
Corresponding Author: \\ Indre Graunaite \\ Eiveniu 2, \\ LT-50009, Kaunas \\ Lithuania \\ Phone: +37068627610 \\ E-mail: igraunaite@gmail.com
}

\begin{abstract}
Objectives: This review article discusses the host response in apical periodontitis with the main focus on cytokines, produced under this pathological condition and contributing to the degradation of periradicular tissues. The pace of research in this field has greatly accelerated in the last decade. Here we provide an analysis of studies published in this area during this period.

Material and Methods: Literature was selected through a search of PubMed electronic database. The keywords used for search were pathogenesis of apical periodontitis cytokines, periapical granuloma cytokines, inflammatory infiltrate apical periodontitis. The search was restricted to English language articles, published from 1999 to December 2010. Additionally, a manual search in the cytokine production, cytokine functions and periapical tissue destruction in the journals and books was performed.

Results: In total, 97 literature sources were obtained and reviewed. The topics covered in this article include cellular composition of an inflammatory infiltrate in the periapical lesions, mechanisms of the formation of the innate and specific immune response. Studies which investigated cytokine secretion and functions were identified and cellular and molecular interactions in the course of apical periodontitis described.

Conclusions: The abundance and interactions of various inflammatory and anti-inflammatory molecules can influence and alter the state and progression of the disease. Therefore, periapical inflammatory response offers a model, suited for the study of many facets of pathogenesis, biocompatibility of different materials to periapical tissues and development of novel treatment methods, based on the regulation of cytokines expression.
\end{abstract}

Keywords: periapical periodontitis; bone resorption; cytokines; cellular immune response; adaptive immunity; pathogenesis.

Accepted for publication: 3 September 2011

To cite this article:

Graunaite I, Lodiene G, Maciulskiene V. Pathogenesis of Apical Periodontitis: a Literature Review.

J Oral Maxillofac Res 2011 (Oct-Dec);2(4):e1

URL: http://www.ejomr.org/JOMR/archives/2011/4/e1/v2n4e1ht.pdf

doi: $10.5037 /$ jomr.2011.2401 


\section{INTRODUCTION}

Apical periodontitis (AP) is an inflammation and destruction of periradicular tissues. It occurs as a sequence of various insults to the dental pulp, including infection, physical and iatrogenic trauma, following endodontic treatment, the damaging effects of root canal filling materials.

In response, the host mounts an array of defenses, consisting of several classes of cells, intercellular messengers, antibodies and effector molecules. The microbial factors and host defense forces encounter, clash with, and destroy much of the periapical tissue, resulting in a formation of various kinds of AP lesions, which most commonly take the form of reactive granulomas and cysts, with the concomitant resorption of bone surrounding the roots of affected teeth.

The pathogenesis of AP has been well reviewed $[1,2]$. However, the introduction of immunohistological methods, intensive use of monoclonal antibodies against subsets of $\mathrm{T}$ lymphocytes, B lymphocytes, macrophages, dendritic cells, plasma cells and polymorphonuclear leukocytes (PMNs) resulted in a major breakthrough in the understanding of periapical host response.

The purpose of the present review is to overlook the factors, which interfere with the pathogenesis of AP and subsequent bone loss, evaluating findings, published in the vast literature on this subject.

\section{MATERIAL AND METHODS}

Literature was selected through a search of PubMed electronic database. The keywords used for search were pathogenesis of apical periodontitis cytokines, periapical granuloma cytokines, inflammatory infiltrate apical periodontitis. The search was restricted to English language articles, published from 1999 to December 2010. Additionally, a manual search in the cytokine production, cytokine functions and bone resorption in the journals and books was performed. The included publications covered cellular composition, immunoregulatory mechanisms, the role of cytokines in human radicular cysts and periapical granulomas, as well as subsequent bone destruction and extracellular matrix degradation.

\section{Cellular composition of inflammatory infiltrates in periapical lesions}

Histologically, a dense infiltration of immunocompetent cells is seen in periradicular lesions. The analysis of these cells showed considerable heterogeneity in their number, morphology and phenotypic properties. Therefore, various attempts have been made to obtain evidence by means of immunofluoresence [3] , or immunocytochemistry $[\underline{4}, \underline{5}]$ techniques.

These numbers vary according to the authors, methods used and stage of AP. However, T lymphocytes, B lymphocytes and macrophages are found to comprise the majority of the inflammatory infiltrate.

\section{Innate immunity}

Microorganisms from the infected root canals, predominantly gramnegative anaerobs, produce sufficient amount of lipopolysaccharide (LPS), also known as endotoxin, which egress in high concentrations into the periapical area. LPS activates the complement system via the alternate pathway leading to the generation of chemotactic peptides [6]. Once the pathogenic factor invades the periapical area, two lines of phagocytic cell defense are formed: an inner area, closer to the apex, in which PMNs predominate; and around it the area in which phagocytic macrophages are seen [7].

The tissue response is generally limited to the apical periodontal ligament and the neighboring spongiosa. It is initiated by the typical neurovascular response of inflammation, resulting in hyperemia, vascular congestion, and edema of the periodontal ligament and extravasation of neutrophils [2].

The PMN approach to the site of infection because of the chemotaxis, induced initially by the tissue injury, LPS, complement factor C5a [2]. Neutrophils were long thought to express only CXCR1 and CXCR2 chemokine receptors, which bind interleukin- 8 (IL-8)/CXCL8 and granulocyte chemotactic protein-2 (GCP-2)/CXCL6 []], but it was demonstrated by Menzies-Gow et al. [9] that this type of cells also exhibit CC receptors. Chemokines, known to cause neutrophil chemotaxis, contribute to PMN migration and functionally activate neutrophil leukocytes, are: IL-8/CXCL8, interleukin-1 (IL-1) [7], GCP-2 [10], interleukin-6 (IL-6) [11], interleukin-17 (IL-17) [12], granulocyte colony stimulating factor (G-CSF) and granulocyte-macrophage colony stimulating factor (GM-CSF) [11]. Specific dentin proteins are capable of stimulating neutrophil migration via the induction of keratinocyte-derived chemokine (KC)/CXCL1 and macrophage inflammatory protein-2 (MIP-2)/CXCL2 release [13]. Strong chemotactic agents for neutrophils are neuropeptides calcitonin gene-related peptide (CGRP), substance P (SP) [1] and leukotrien LTB4 [14]. Detectable levels of IL-8/CXCL8 were found in approximately $95 \%$ of periapical exudates collected 
from root canals during routine endodontic treatment of human periapical lesions, suggesting a pivotal role for IL-8 in neutrophil migration in acute phases of apical disease [15]. Positive imunohistochemical staining for IL-8 in the progeny of the epithelial rests of Malassez was demonstrated and it exhibited a characteristic binding pattern to the extracellular matrix of the lesion [16]. Significant source of IL-8 is periapical lesion mononuclear cells that are CD4 + (Th1) and CD11c+ (monocyte-like cells, macrophages, dendritic cells) [17]. Endodontic pathogenic microorganisms Porphyromonas endodontalis, Porphyromonas gingivalis and Prevotella intermedia are able to induce the production of IL- 8 by pulp fibroblasts and osteoblasts [18]. This production by pulp cells is modulated by neuropeptides, such as SP and CGRP $[19,20]$.

IL-8 chemotactically attracts and activates PMNs, making them more available and more competent to engage and kill the bacteria [7], stimulates osteoclast recruitment and activity [21]. Besides, positive correlation between the levels of IL-8 and pain symptoms was found in periodontal lesions [22].

The GCP-2 (CXCL6) is a CXC chemokine. Similar to IL-8, it possesses potent chemotactic and proangiogenic properties [23]. Kebschull et al. [10] suggested that GCP-2 expression originates from the microvascular endothelium of inflamed gingival tissue in periodontal diseases.

IL-1 production locally elevates cellular adhesion molecule (CAM-1) expression by endothelial cells in the capillaries, thus enhancing the local attachment of PMNs and monocytes and enhancing their migration into the area [7]. IL-1 has been identified as a central mediator of periapical and pulpal inflammation [1]. It is produced by macrophages []], PMNs [24], osteoclasts [25], cyst epithelial cells [26] and the production and action is regulated by many other cytokines: interleukin-12 (IL-12), interferon gamma (IFN $\gamma$ ), tumor necrosis factor alpha (TNF $\alpha$ ) and IL-1 itself as inducers; interleukin-4 (IL-4), IL-6, interleukin-10 (IL-10) and interleukin-13 (IL-13) as suppressors [1].

There are two distinct isoforms of IL-1: interleukin-1 alpha (IL- $1 \alpha)$ and interleukin- 1 beta (IL-1 $\beta)$. IL- $1 \beta$ is a predominant form found in human periapical lesions [24].

IL-1 together with IL-6 and TNF have been shown to induce an acute-phase response- fever, an elevation in the erythrocyte sedimentation rate and major shifts in the types of serum proteins synthesized by hepatocytes [11]. Local effects of IL-1are enhancement of leukocyte adhesion to endothelial walls, stimulation of lymphocytes, potentiation of neutrophils, activation of the production of prostaglandins and proteolytic enzymes, enhancement of bone resorption, inhibition of bone formation [2]. The IL-1 together with TNF $\alpha$ are also known to induce the production of downstream mediators such as IL-6 and IL-8 [1].

The IL-6 is an integral mediator of the acute phase response to injury and infection. The major sources of IL-6 production are monocytes and macrophages, type 2 helper T lymphocytes (Th2), activated B cells and PMN cells. Epithelial cells, vascular endothelial cells and fibroblasts have also been shown to release IL-6 $[6,11,27]$. Local effects of IL-6 are: stimulates the differentiation of mature B lymphocytes into antibody producing plasma cells, activates $T$ cells, augments neutrophil cytotoxic activity, induces bone resorption both alone and in concert with IL-1 and lipopolysacharide, down-regulates the production and counters some of the effects of IL-1 [11]. Experiments on IL-6 deficient mice revealed the fact that IL-6 possesses both proinflammatory and anti-inflammatory properties and its final effect depends on the target cells and interplay with other cytokines $[\underline{5}, \underline{28}]$.

The IL-17 is secreted by type 17 helper T lymphocytes (Th17). It is able to reactivate the inflammatory process including the induction of inflammation characterized by the presence of neutrophils. There is also strong evidence that IL-17 might induce the production of receptor activator for nuclear factor kappa B ligand (RANKL), activating osteoclasts, with consequent bone resorption [12].

Colony stimulating factors (CSF) are a group of cytokines that regulate the proliferation and differentiation of hematopoietic cells. They functionally activate neutrophil leukocytes. GM-CSF is secreted by a large variety of cells, the possible principle sources being macrophages, endothelial cells, activated $\mathrm{T}$ cells and PMN [11].

Specific dentin proteins are capable of stimulating neutrophil migration via the induction of $\mathrm{KC} / \mathrm{CXCL} 1$ and MIP-2/CXCL2 release [13]. There is a data, confirming that KC/CXCL1 and MIP-2/CXCL2 together with IL-8/CXCL8 are the most critical CXC chemokines for neutrophil recruitment [29].

The CGRP is a 37 -amino-acid peptide which is widely distributed throughout the central and peripheral nervous systems and is found in particularly high levels in sensory nerves. CGRP has potent vasodilator activity and is frequently co-localized with SP [30]. Kabashima et al. [31] investigated periapical granulomas by the means of immunohistochemical methods and found that CGRP- and SP-immunoreactive nerve fibers are localized in the vicinity of blood vessels.

The SP stimulates the release of histamine from the mast cells, which in turn results in increased bradykinin production, while bradykinin, histamine and prostaglandin E2 (PGE2) all stimulate increase in pulpal 
vascular permeability. SP also increases phagocytosis and oxidative metabolism [1] .

The LTB4 is formed when arachidonic acid is oxidized via the lipoxygenase pathway. It causes PMNs adhesion to the endothelial walls and attracts macrophages into the area. Besides PMNs are not only attracted by LTB4, but also release them and prostaglandins. So though neutrophil leukocytes are essentially protective cells, they also cause severe damage to the host tissues [2].

The PMNs produce a wide range of cytokines: IL-1, TNF- $\alpha$, IL-6, IL-8, macrophage inflammatory proteins MIP- $1 \alpha$ and MIP-1 $\beta[\underline{6}, \underline{11}, \underline{24}, \underline{32}, \underline{33}]$, which act as the chemoattractants for other inflammatory cells or PMNs themselves and contribute to the bone resorption. These cells are also considered to be the source of SP [34].

The PMNs are the short lived cells. Their massive death is a major cause for tissue breakdown in acute phases of apical periodontitis [2] and so the space for other cell infiltration to the periodontal area is provided. Another type of cells, which enter the site of inflammation is macrophages.

Frequency of macrophages within the inflammatory cellular infiltrate has been reported to scatter between wide ranges of $4 \%$ to over $50 \%$. This difference considered to be an outcome of using the different methodology. Introduction of the immunohistological methods is considered to be the breakthrough in identifying macrophages and their subsets [6].

Infiltration of macrophages into sites of inflammation is relatively slow compared to that of neutrophils, but they are capable to engulf almost any foreign agent and their infiltration lasts for a longer time. They were shown to express CC chemokine receptors: CCR1, CCR2 and CCR5 [35]. Potential chemoattractants and activators for macrophages are: monocyte chemoattractant protein-3 (MCP-3) [6, 36], GM-CSF [11], MIP-1 $\alpha / \mathrm{CCL} 3$, MIP-1 $\beta / C C L 4$ [33], transforming growth factors type $\beta$ (TGF- $\beta$ ), CGRP, SP [1] ], LTB4 [2]], LPS [ $[\underline{6}$,$] ,$ IFN- $\gamma[$ [7] and TNF $\alpha$ [1].

The MCP-3/CCL7 is one of the most pluripotent chemokines, but it acts predominantly on monocytemacrophage lineage [37]. MCP-3 is expressed by endothelial cells, plasma cells, lymphocytes and fibroblasts induced by IL- $1 \beta$, TNF- $\alpha$, IFN- $\gamma$ and LPS $[36,38]$.

The MIP- $1 \alpha /$ CCL3 3 and MIP-1 $\beta /$ CCL 4 belong to the CC chemokine family. Type 1 helper T lymphocytes (Th1) can attract and activate macrophages by producing cytokines MIP- $1 \alpha$ and MIP-1 $\beta$ [39].

The TGF- $\beta$ family members are critical regulators of cell growth, differentiation, repair and inflammation. TGF- $\beta$ is one of the cytokines involved in the repair process in periradicular lesions and belongs to the group of anti-inflammatory cytokines [40]. Production of the isoform TGF- $\beta 1$ can be stimulated by microbial products, the host response to antigens and tissue injury itself [1]. Although the main source is activated macrophages and eosinophils, lymphocytes, fibroblasts, osteoblasts and osteoclasts are also capable of TGF- $\beta$ formation [40]. In early phases of the inflammatory response TGF- $\beta 1$ is a chemoattractant for monocytes and lymphocytes, recruiting them to the site of injury. However, subsequently it exerts potent suppressive effects on the proliferation and differentiation of both $\mathrm{T}$ and $\mathrm{B}$ lymphocytes, inhibits the production of IL-1, IL-2, IL-6, TNF $\alpha$ and IFN $\gamma$, antibody secretion, blocks nitric oxide (NO) production by macrophages [1], accelerates healing by stimulating the repair of soft and hard tissues and also inhibits osteoclast formation [40]. Teixeira et al. [41] reported that levels of TGF- $\beta$ were significantly higher on granulomas compared to radicular cysts, suggesting that periapical granulomas display a regulatory pattern with high levels of TGF- $\beta$ and low levels of proinflammatory cytokines.

The IFN- $\gamma$ is a cytokine, produced by Th1 cells. The secretion of IFN- $\gamma$ is primarily triggered by IL-12 and down-regulated by IL-10. Both IL-12 and IL-10 are produced by dendritic cells and activated macrophages [42]. IFN- $\gamma$ activates macrophages, reduces macrophage-suppressive activity, and induces IL-1, NO synthesis and O2- production [43]. TeixeiraSalum et al. [41] reported possible IFN- $\gamma$ association with clinical symptoms. Lesions that presented higher levels of reactivity to IFN- $\gamma$ and interleukin-4 (IL-4) were associated with percussion and palpation tenderness. Swelling was associated with high levels of IL- 4, TNF- $\alpha$ and IFN- $\gamma$. On the other hand, Ataoglu et al. [44] failed to show the correlation between TNF- $\alpha$ levels and clinical symptoms.

The TNF $\alpha$ is produced both by macrophages and Th1 lymphocytes [1]. LPS, released from the infected root canals, stimulates macrophages to secrete proinflammatory cytokines, such as IL-1 and TNF $\alpha$ [45]. The biological effects of TNF- $\alpha$ include activation of leukocytes such as lymphocytes ( $\mathrm{T}$ and B cells), macrophages and natural killer cells; fever induction; acute-phase protein release; cytokine and chemokine gene expression and endothelial cell activation $[24,40,46]$. This cytokine is reported to stimulate bone resorption. However, IL- 1 has been found to be 500 -fold more potent than $\mathrm{TNF} \alpha$ in mediating bone resorption [그.

When present at the site of inflammation, macrophages have central roles in the regulation of connective tissue destruction and repair; innate, nonspecific immunity and the onset, regulation and outcome of antigen-specific, acquired, immunity [7]. In response to bacterialencounter or activation signal of another 
nature they produce a variety of biologically active molecules which are cytokines IL-1, TNF $\alpha$ [1] , IL-8 [6], IL-6, GM-CSF [11], IL12 [1], IL-10 [5], growth factors, IFN $\alpha$, IFN $\beta$ [2], arachidonic acid metabolites, free radicals, metalloproteinase enzymes [] $] \beta$-endorphin and Met-enk [1]. Macrophages may also serve as antigen-presenting cells (APCs) in the essential initial steps of the induction of acquired immunity. They process the antigen and present it to the antigen-specific clones of $\mathrm{T}$ helper lymphocytes by a process involving the recognition by the lymphocytes of an MHC II molecule on the macrophages [7].

Development of an effective adaptive immune response relies greatly upon appropriate recognition of antigen by cells of the innate

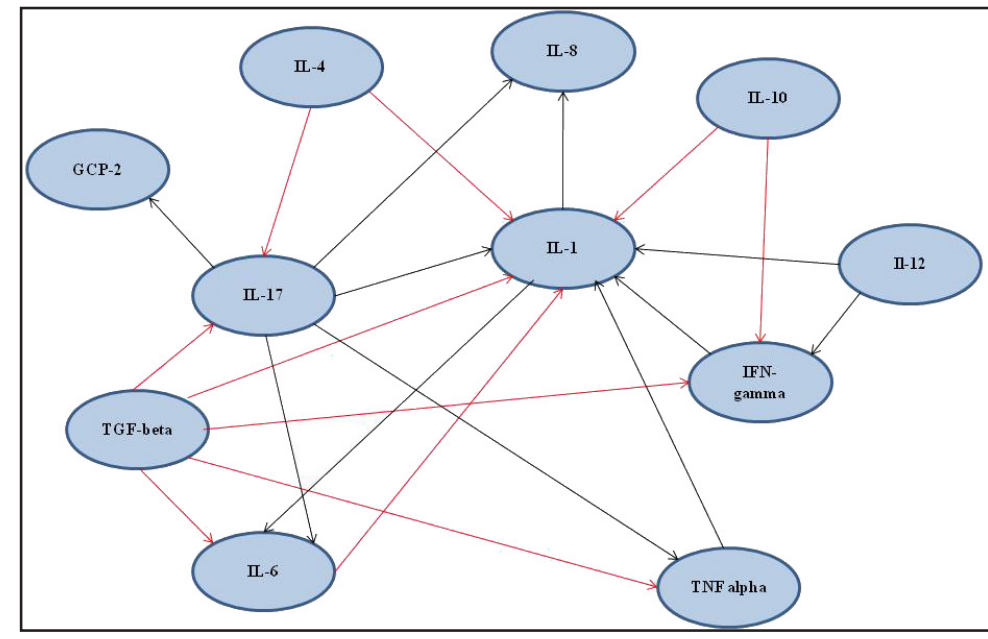

Figure 1. Cytokines interaction in the course of apical periodontitis. Black arrow $=$ stimulation; red arrow $=$ suppresion . immune system and presenting it to adaptive immune cells. The APCs have important pathogen recognition skills and operate at the interface of innate and adaptive immunity. However, even if a considerable proportion of macrophages in the lesion may express major histocompatibility complex (MHC) class II molecules, suggesting that they may act as APCs, recent researches showed that dendritic cells act as efficient APCs, compared to macrophages [48].

Dendritic cells function as sentinels of the immune system by trafficking from the vasculature to the tissues where, while immature, they capture antigens. The APCs possess special receptors on their surface that recognize specific pathogen associated molecular pattern (PAMP) and trigger appropriate intra-cellular events to continue capture of antigen and further induce co-stimulatory molecules for T cells. In humans, Tolllike receptors (TLRs) identify PAMPs and activate multiple steps in the inflammatory reaction. Once activated, TLRs up regulate the genes encoding inflammatory cytokines such as IL-8, TNF $\alpha$, IL-6, IL-12 and IL-1 $\beta$ in immunocompetent cells. Appropriate ligand recognition by TLRs stimulates intracellular signal transduction pathways and induction of different genes that function in host defense, including those for inflammatory cytokines, chemokines, MHC and co-stimulatory molecules. In addition, TLR activation induces multiple effector molecules, such as inducible nitric oxide synthase and antimicrobial peptides, which can destroy microbial pathogens. Then, following inflammatory stimuli, antigen loaded dendritic cells leave the tissues and move to the draining lymphoid organs where, converted into mature dendritic cell, they prime naive T cells [49].

The RANKL is an important regulator of the interactions between $\mathrm{T}$ cells and dendritic cells during the antigen presentation process. RANKL is also expressed on the surface of the dendritic cells and the interaction with its receptor can induce cluster formation and activation of $\mathrm{T}$ cells, dendritic cell survival, regulate the dendritic cell functions, and T cell-dendritic cell communication [무].

\section{Adaptive immunity}

Continuous or severe infections at levels beyond the capacity of innate immunity are mediated by adaptive immunity, which is much more specific toward exogenous antigens. Adaptive immunity is also called specific immunity, and possesses the ability to memorize and respond more vigorously to repeated exposures to the same antigen. The major components of adaptive immunity are $\mathrm{T}$ and $\mathrm{B}$ lymphocytes [51].

$\mathrm{T}$ lymphocytes are classified into two categories according to their surface $\mathrm{T}$ cell receptors (TCRs), which are either the alpha- beta $(\alpha \beta)$ or gamma- delta $(\gamma \delta)$ type. Although the functions of TCR $\gamma \delta$ - expressing cells are still uncertain, they are reportedly related to nonspecific defense systems against exogenous stimuli [51]. The majority of T cells express an antigen-specific receptor composed of $\alpha$ and $\beta$ chains. Cell surface expression of $\mathrm{CD} 4$ and $\mathrm{CD} 8$ co-receptor molecules divides mature $\alpha \beta \mathrm{T}$ cells into two subsets [6]. CD4+ cells working with B lymphocytes have been known as $\mathrm{T}$ helper/inducer cells (Th/i). CD8+ cells have direct toxic and suppressive effects on other cells and have been named $\mathrm{T}$ cytotoxic/suppressive $(\mathrm{Tc} / \mathrm{s})$ [2]. The CD4+ cells differentiate further into two types, known as Th1 and Th2 cells, according to the cytokines that these cells produce. Both types of effector responses are regulated by a heterogeneous family of cells, which is known as regulatory $\mathrm{T}$ (Treg) cells. They form a subset of $5-10 \%$ of CD4+ T cells [52]. Recently, a new subset of Th cells that predominantly produce IL-17 
has been discovered and named as Th17.

The understanding about the role of suppressor/ regulatory $\mathrm{T}$ cells changed a few times through the time. Initially it was considered that these cells were CD8+, later that they do not exist at all. Everything changed when the forkhead/winged helix transcription factor (Foxp3), known as a key orchestrator of inhibitory function, was discovered. Such T cells occur within both the CD4 and the CD8 T cell lineages. Their suppressive functions are inhibition of antigen presenting cells and production of inhibitory cytokines [ $\underline{53}]$.

The CD8+ cells are also known to induce target cell death by means of granule- and FAS- mediated pathways and have cytotoxic effects when secreting several cytokines, such as TNF $\alpha$ and IFN $\gamma$, in the vicinity of target cells [51]. Cytokines known to be involved in the recruitment of CD8+ cells are MIP-1 $\alpha$, MIP-1 $\beta$ and IFN $\gamma$ induced protein (IP)-10 [12].

IP-10/CXCL10 is expressed by various inflammatory cells as well as endothelial cells. It was also reported to attract Th1 cells [54].

The Th1 type response can be characterized by the production of IL-12, IFN- $\gamma$ [52] and TNF- $\alpha$ [41].

The IL-12 is produced by activated APC, such as macrophages [1]. It is involved in Th1 cells differentiation from the native $\mathrm{T}$ helper cells and together with IFN- $\gamma$ inhibits Th2 differentiation [39].

The IFN- $\gamma$, as noted before, is produced by Th1 cells. And it mainly serves to activate macrophages at the site of inflammation.

The TNF- $\alpha$ is produced both by macrophages and Th1 lymphocytes [1]. The biological effects of TNF- $\alpha$ include activation of leukocytes such as lymphocytes ( $T$ and B cells), macrophages, and natural killer cells [46]. Differentiation of native $\mathrm{T}$ cells to $\mathrm{Th} 2$ lymphocytes is driven by the activation of T cells via TCR and IL-4 receptor, which leads to phosphorylation of signal transducer and activator of transcription, interleukin-4 induced (STAT6). The pSTAT6 is critical for the induction of the Th2 transcription factor GATA3, which in turn transactivates $\mathrm{Th} 2$ specific cytokines, such as IL-4 [39]. Th2 response also can be characterized by the production of IL- 6 [52].

IL-4 has been found in periapical granulomas and cysts: Ihan Hren and Ihan [55] established that high IL-4 production is a characteristic of established $\mathrm{RC}$, while de Sa et al. [ㄷ] found IL-4 positive cells in periapical granulomas. Its anti-inflammatory effects have been described to be essential for the modulation of the periapical bone remodeling process. It seems to exert an inhibitory effect on bone resorption by decreasing osteoclastic activity $[41,57]$.

Differentiation of Th17 lymphocytes from the native $\mathrm{T}$ cells is driven by the combination of the cytokines
TGF- $\beta$ and IL-6. In the absence of IL-6, Th17 differentiation can also be induced by TGF- $\beta$ plus IL-21. IL-23, produced by APC, reinforces Th17 differentiation programme and decreases the chance of dedifferentiation and plasticity in Th17 cells. IL- $1 \beta$ was also described as critical differentiation factor for Th17 cells. In addition, as Th1 and Th2 subsets cross-regulate each other, they also appear to regulate the development of Th17 cells, because both IFN- $\gamma$ and IL-4 inhibit the formation of Th17 [39].

The Th17 cells produce IL-17, which is able to reactivate the inflammatory process, including the induction of inflammation characterized by the presence of neutrophils [12]. That is so because of the ability of IL-17 to induce proinflammatory cytokines like IL1, IL-6 and TNF, and proinflammatory chemokines like CXCL1, GCP-2 and IL-8 [누, $\underline{58}]$. Th17 cells also regulate osteoclastogenesis, possibly through IL-17 mediated induction of RANKL on osteoclastogenesis supporting cells [ $\underline{52]}$.

There is evidence that the type of the immune response in the periapical granuloma tissue is determined by their apically resident bacteria $[\underline{55}, \underline{59}]$.

Minor population of CD4+ T cells, which coexpress the IL-2 receptor $\alpha$-chain (CD25) and are crucial for the control of auto reactive $T$ cells and the regulation of the immune response to infection, is named "T regulatory cells" (Treg). They were found to express the Foxp3, which is uniquely present in this cell type and is essential for Treg differentiation [60].

The TGF- $\beta$ alone induces the Treg transcription factor Foxp3 and is also essential for Treg development [39]. Therefore a close relationship between Th17 vs. Treg immune response exists. The amount of TGF- $\beta$ as well as the presence or absence of proinflammatory cytokines determines whether the immune response will be Th17 or Treg [12]. The presence of pro-inflammatory cytokines, like IL-6, which is induced during infection, inflammation or injury, inhibits the induction of Foxp3+ Tregs and simultaneously promotes Th17 cell differentiation [39].

B lymphocytes are the lymphocytes, directly responsible for antibody production. On receiving signals from antigens and the Th2 cells, some of the B cells transform into large plasma cells [51]. B lymphocytes and their progeny, plasma cells producing IgG, IgA and IgM, were repeatedly shown in the periradicular granulation tissue $[\underline{3}, \underline{4}, \underline{61}]$.

\section{Destruction of the periapical bone}

The integrity of bone tissues depends on the maintenance of a delicate equilibrium between bone resorption by osteoclasts and bone deposition by osteoblasts. 
Table 1. Cytokines, involved in immune response formation in apical periodontitis $[\underline{1}, \underline{2}, \underline{6}, \underline{7}, \underline{10-12}, \underline{17}, \underline{22-27}, \underline{36-43}, \underline{45}, \underline{52}, \underline{57}]$

\begin{tabular}{|c|c|c|}
\hline Cytokines & Source & Primary functions \\
\hline IL-1 & MǾ, PMN, Oc, Epithelial cells & $\begin{array}{l}\text { Chemotactically attracts and activates PMNs; } \\
\text { Stimulates the production of prostaglandines, proteolytic enzymes and } \\
\text { cytokines IL-6, IL-8; } \\
\text { Stimulates bone resorption and inhibits bone formation }\end{array}$ \\
\hline IL-8 & MǾ, PMN, Th1 & $\begin{array}{l}\text { Chemotactically attracts and activates PMNs; } \\
\text { Stimulates osteoclast recruitment and activity }\end{array}$ \\
\hline IL-6 & MǾ, PMN, Th2, B lymphocytes, endothelial cells & $\begin{array}{l}\text { Activates PMNs, T cells; } \\
\text { Stimulates the differentiation of B lymphocytes into plasma cells; } \\
\text { Induces bone resorption; } \\
\text { Down-regulates the production of IL-1 }\end{array}$ \\
\hline $\mathrm{TNF} \alpha$ & MǾ, Th1, PMN & $\begin{array}{l}\text { Activates lymphocytes and MǾ‘s; } \\
\text { Stimulates bone resorption }\end{array}$ \\
\hline GCP-2 & Endothelial cells & Chemotactically attracts PMNs \\
\hline IL-17 & Th17 & $\begin{array}{l}\text { Activates IL-1, IL-6, TNF } \alpha, \text { GCP- } 2 \text { and IL- } 8 \text { secretion; } \\
\text { Stimulates bone resorption }\end{array}$ \\
\hline GM-CSF & MǾ, T lymphocytes, endothelial cells, PMN & Functionally activates MǾ and PMNs \\
\hline MCP-3 & $\begin{array}{l}\text { Endothelial cells, lymphocytes, fibroblasts, plasma } \\
\text { cells }\end{array}$ & Chemotactically attracts Mǿ \\
\hline MIP-1 & Th1 & Chemotactically attracts and activates MǾ and Oc \\
\hline TGF $\beta$ & MǾ, lymphocytes, fibroblasts, Ob, Oc & $\begin{array}{l}\text { Suppresses the proliferation and differentiation of T and B lymphocytes; } \\
\text { Down regulates the production of IL-1, IL-6, TNF } \alpha \text { and IFN } \gamma \text {; } \\
\text { Blocks the production of nitric oxide by MǾ; } \\
\text { Inhibits bone resorption; } \\
\text { Inhibits Th17 formation and promotes Treg formation }\end{array}$ \\
\hline $\mathrm{IFN} \gamma$ & Th1 & $\begin{array}{l}\text { Activates Mǿ; } \\
\text { Induces IL-1, } \mathrm{NO} \text { and } \mathrm{O}_{2} \text { production }\end{array}$ \\
\hline IL-12 & MǾ, dendritic cells & $\begin{array}{l}\text { Stimulates the production of IL-1 and IFN } \gamma \text {; } \\
\text { Stimulates Th1 differentiation; } \\
\text { Suppresses Th2 differentiation }\end{array}$ \\
\hline IL-10 & MǾ, dendritic cells & Suppresses the production of IL-1 and IFN $\gamma$ \\
\hline IL-4 & Th2 & $\begin{array}{l}\text { Inhibits bone resorption; } \\
\text { Inhibits Th17 formation, } \\
\text { Suppresses the production of IL-1 }\end{array}$ \\
\hline
\end{tabular}

MǾ = macrophages; $\mathrm{PMN}=$ polymorphonuclear leucocytes; $\mathrm{Th}=\mathrm{T}$ helper cells; $\mathrm{Ob}=$ osteoblasts; $\mathrm{Oc}=$ osteoclasts; $\mathrm{NO}=$ nitric oxide.

Osteoclasts originate from hematopoetic precursors of the monocyte-macrophage lineage that reside within the bone marrow and, guided by chemokines, emigrate from the peripheral circulation into bone. Chemokines, known to cause osteoclasts chemotaxis and differentiation, are: MCP-1/CCL2, SDF-1 $\alpha /$ CXCL12, MIP-1 $\alpha /$ CCL3, MIP-1 $\gamma /$ CCL9, RANTES/CCL5, IL-8/CXCL1, MCP-3/CCL7, CKß8/ CCL23, MIG/CXCL9 and IP-10/CXCL10. The activation of osteoclasts is achieved only with RANKL [15].

Marton et al. [16] reported that the recruitment into granuloma lesions of monocytes may be due to the presence of MCP-1. MCP-1/CCL2 is associated with osteoclast chemotaxis and differentiation, probably through the interaction with receptor CCR2 [15].

Stromal derived factor- $1 \alpha$ or CXC chemokine ligand 12 (SDF-1 $\alpha /$ CXCL12) is selectively expressed by endothelial cells in certain tissues, perhaps in response to specific signals or tissue damage. The interaction of SDF-1 with its receptor CXCR4, which is expressed in human osteoclast precursors, induces chemotaxis and differentiation into osteoclasts [62]. Human neutrophils have been found to respond chemotactically to SDF-1 $\alpha$ in vitro in the periodontal disease model [63]. In addition, it was found to increase matrix metalloprotease (MMP)9 activity in human osteoclasts, resulting in increased bone resorptive activity [15]. Fukada et al. [52] noted that expression of SDF- $1 \alpha$ was higher in cysts compared with granulomas.

The MIP- $1 \alpha /$ CCL3 induces adhesion of osteoclasts to primary osteoblasts, thereby suggesting a function for this chemokine in regulation of the interaction between those two cell types. The MIP-1 $\gamma /$ CCL9 plays an important role in the survival of osteoclasts, and part of the RANKL effect on osteoclast survival is dependent on its ability to induce MIP- $1 \gamma /$ CCL9 production [15]. 
Regulated on activation, normal $\mathrm{T}$ cell expressed and secreted (RANTES/CCL5) is a member of the CC chemokine family. Yu et al. [64] found that RANTES, MIP- $1 \alpha$ or MCP-3 significantly and dose-dependently stimulated the migration of RAW or primary marrow cells through the porous inserts, RANTES or MCP-3 dramatically increased M-CSF/RANKL induced osteoclast (OC) formation in the marrow cultures by enhancing the fusion of precursors to generate larger more multinucleated OCs. MIP- $1 \alpha$ and RANTES were endogenously released at varying levels in cultures of pre-OCs, OCs or odontoblasts (OBs) of different stages of differentiation.

The $\beta$-chemokine (CK $\beta 8 / C C L 23)$ is a member of the CC chemokine family. Functionally, CCL23 has chemotactic activity for monocytes, dendritic cells, lymphocytes, neutrophils, osteoclast precursor cells, and endothelial cells [두].

Osteoclast precursors have also been found to express CXCR3, which make them responsive to the chemokine MIG/CXCL9 and results in their migration and the adhesion of osteoclast precursors [15].

$\mathrm{T}$ cells are able to regulate osteoclastogenesis by the RANKL and IFN- $\gamma$ production [66]. RANKL is one particular molecule found on the surface of activated $\mathrm{T}$ cells that has also been found to activate bone-resorbing cells [67]. Fukada et al. [52] suggested that Th1 response could be modulating RANKL expression and osteoclastogenesis in human granulomas. RANKL acts through the binding to its receptor RANK, a cell-surface protein, which is present on osteoclast precursor cells and, when activated, promotes osteoclast maturation by increasing the expression of specific genes [68]. RANKL activates the TNF receptor associated factor 6 (TRAF6), c-Fos and calcium signaling pathways all of which are indispensable for the induction and activation of NFATc1 (nuclear factor of activated T cell $\mathrm{c} 1$ ) - the master transcription factor for osteoclastogenesis [66]. Takayanagi et al. [69] showed that NFATc1 deficient embryonic stem cells were unable to differentiate into osteoclasts after RANKL stimulation. Thus NFATc1 is viewed as a critical transcription factor that acts as a master switch for osteoclast differentiation and maturation. NFATc1 role might also change to regulating the differentiation and function of lymphocytes during the later inflammation stages [66].

Vernal et al. [50] demonstrate a clear relation between high RANKL levels and monocyte activity during periapical bone destruction in periapical granuloma. Haynes et al. [70] showed that human monocytes express RANKL mRNA when stimulated by prosthetic wear debris thought to cause osteoclast formation in periprosthetic osteolysis in vitro. Chen et al. [71] found that RANKL was expressed in an osteoblastic cell line.
It was observed that cells expressing the macrophage marker CD68 also expressed RANKL. However, it is not possible to assure that these macrophages are indeed the source of this RANKL, because they may express RANKL on their surface bound to a RANK derived from anothercell [68]. In agreement with that, Kawashima et al. [72] reported that RANKL+ cells were not positive for Ia antigen, indicating that activated macrophages and dendritic cells did not express RANKL.

The natural decoy receptor for RANKL is osteoprotegerin (OPG), also known as osteoclastogenesis inhibitory factor (OICF), and osteoclast formation is regulated by the balance between OPG and RANKL [72]. OPG, a soluble TNF receptor-like molecule, produced by human periodontal ligament cells, gingival fibroblasts, and epithelial cells, binds to RANKL and prevents it from binding to RANK. This effectively inhibits RANKL mediated osteoclast maturation. The triad RANK/RANKL/OPG is a key regulator of bone remodeling, and is essential for the development and activation of osteoclasts [68].

It has become evident that osteoblasts have a global role in orchestrating the bone remodeling process. Their function is not restricted solely to bone formation, but it is now firmly established that they are responsible for initiating bone resorption. Osteoblasts provide the essential and sufficient stimuli that control the behavior of the osteoclasts, an event that occurs via cell-cell interaction. There are molecular determinants responsible for that, namely M-CSF and RANKL, the former secreted and the latter mainly cell-membrane bound. The M-CSF binds to c-Fms on the surface of osteoclast precursors and so enhances their proliferation and survival [73].

\section{Enzymes involved in degradation of the extracellular matrix (ECM)}

The periodontal ligament is a dense connective tissue, localized between the cementum and alveolar bone, supporting the tooth. This ligament is composed mainly of collagen fibers and elastic system fibers. The destruction of the periodontal ligament is initiated by the degradation of ECM. Enzymes involved in ECM degradation comprise both matrix metalloproteinases (MMPs) and serine proteases (including neutrophil elastase and cathepsin G) [74].

The MMPs are a family of zinc- dependant endopeptidases collectively capable of degrading all extracellular matrix components, including collagen and proteoglycans. The MMPs have been suggested to play an important role in inflammatory conditions of periodontal, pulpal and periapical tissues, as well as dentin mineralization [ㄷ]. Tjaderhane et al. [76] 
demonstrated that in periapical inflammation MMP inhibition increases the lesion growth rate, indicating that MMPs may have previously unknown anti-infective and/or anti-inflammatory properties. MMPs have been divided into four subfamilies: collagenases, gelatinases, stromelysins and membrane type MMPs, according to their substrates and structures, collagenases and gelatinases being the most widely investigated in apical periodontitis lesions.

The subfamily of collagenases includes: interstitial collagenase (MMP-1), collagenase of neutrophils (MMP-8) and collagenase-3 (MMP-13). These enzymes disintegrate native fibrillar interstitial collagens by cleaving the single peptide bond $\alpha$-chains [77].

The MMP-1 has been reported to degrade nonmineralized extracellular matrix and stimulate osteoclastogenesis through generating collagendegradation fragments on bone surfaces. MMP-1 expressing cells are considered to be macrophages $[\underline{78}, \underline{79}]$. Hong et al. [46] investigated the role of LPS on the expression of MMP-1 by macrophages in rats. It was suggested that LPS, released from the infected root canal, triggers the production of IL- $1 \alpha$ and TNF- $\alpha$ from macrophages. These pro-inflammatory cytokines modulate the subsequent production of MMP-1 from macrophages to promote periapical bone resorption.

The MMP-8 (collagenase-2) degrades gelatin, type I, II, III, V and XI collagens [74]. Wahlgren et al. [80] reported that PMN cells and macrophage like cells expressed the staining with MMP-8 specific antibody, the PMN cells being the predominant cell type to express MMP-8 in apical periodontitis. Reynaud Af Geijersstam et al. [81] tested the effect of Enterococcus faecalis (E. faecalis) strains on the production of MMP-8. The majority of the E. faecalis strains induced little or no release of this enzyme from the PMN cells. By this finding they partly explained the clinical observation that root canal infections dominated by E. faecalis are usually symptom free.

The MMP-13 has an exceptionally wide substrate specificity compared with other MMPs. In addition to fibrillar type I, II and III collagens, MMP-13 degrades type IV, IX, X and XIV collagens, gelatin, tenacin-C, fibronectin and proteoglycan core proteins [82] Studying the role of MMP-13 in apical periodontitis, Leonardi et al. [77] found that MMP-13 may provide the support for the conversion of a periapical granuloma with epithelium into a radicular cyst, due to the capability of the MMP to influence not only epithelial cell rest migration, but also the invasion of the granulomatous tissue.

Type IV collagen/gelatin is the main component of basement membrane and the degradation of this structural protein as well as denatured gelatins, laminin, elastin, fibronectin and basement membrane zoneassociated collagen is favored by 2 MMPs: gelatinase A (MMP-2) and gelatinase B (MMP-9) $[74,83,84]$.

The MMP-2 is known to degrade gelatin, fibronectin, elastin, laminin and collagen I, III, IV, V, VII, X, XI [요].

The MMP-9 degrades gelatin, elastin, type IV, V, VII, $\mathrm{X}, \mathrm{XI}$ and XIV collagens. It is mainly secreted by neutrophils, although macrophages, $T$ cells, mast cells and odontoblasts can also express this enzyme [74].

Several studies have shown that MMP-2 and -9 participate in the pathogenesis of pulp and periapical inflammation. Shin et al. [85] detected MMP-2 in chronic periapical lesions by immunohistochemistry and Buzoglu et al. [75] used gelatin zymography detecting pro- and active forms of MMP-9 in all intracanal pus samples with apical abscess. On the other hand, MMP-2 could not be detected in chronic apical abscess samples, although detected in samples of primary and secondary acute apical abscesses.

Belmar et al. [86] demonstrated that MMP-9 and -2 are highly increased in gingival crevicular fluid (GCF) from teeth with periapical lesions and suggested that these gelatinases could represent useful markers in monitoring chronic apical periodontitis in GCF. IL- $1 \alpha$, TNF- $\alpha$ and bacterial LPS can stimulate gelatinase expression in pulp fibroblasts in vitro $[87,88]$.

Serine proteases known to degrade ECM in apical periodontitis are neutrophil elastase (NE) and cathepsin G [74]. Neutrophil elastase (NE) is one of the major enzymes of the azurophilic granules of human neutrophils, and in inflammation its release into periapical tissue could contribute tissue damage. Elastase degrades several proteins including elastin, collagen, fibrinogen, hemoglobin, ground- substance components of connective tissue and proteoglycans [89]. Alptekin et al. [우 ] demonstrated the presence of $\mathrm{NE}$ in periapical exudates of endodontically involved teeth and high levels were associated with presence of some clinical findings such as pus discharge, swelling and sinus tract formation. Thus, it was suggested that NE levels in periapical exudates may be a reliable marker for disease state of periapical lesions. It was also shown that periapical exudate NE levels were correlated with PGE2 levels and the canals with pus discharge contained higher NE and PGE2 total amounts than teeth without these signs [90].

Cathepsin G degrades type III collagen and proteoglycan. It is a nonspecific serine protease which cleaves individual amino acids from protein molecules. Cathepsin $G$ is mainly stored in primary granules of neutrophils and is also detectable in monocytes and mast cells. Tsuji et al. [74] demonstrated that cathepsin G participated in ECM and periapical tissue degradation 
Table 2. Enzymes involved in degradation of the extracellular matrix $[\underline{74}, \underline{78-83}, \underline{89}]$

\begin{tabular}{llll}
\hline & \multicolumn{3}{c}{ Expressing cells } \\
\hline
\end{tabular}

and enhanced the development of periradicular lesion.

\section{The role of reactive oxygen species}

Reactive oxygen species (ROS) are highly reactive and may modify and inactivate proteins, lipids, DNA, and RNA and induce cellular dysfunctions. $\mathrm{O}_{2-}, \mathrm{H}_{2} \mathrm{O}_{2}$ and NO (nitric oxide) play an important role in the host defense, as well as in inflammation-induced tissue lesions.

Superoxide anion is a highly reactive oxygen radical involved in cell and tissue damage in a variety of disorders, including inflammatory diseases. While production of superoxide by neutrophils and other phagocytic cells is essential for the killing of microorganisms, it causes tissue damage at the site of inflammation. An altered balance between oxygen radical production by phagocytic cells in periapical lesions and its elimination was suggested to contribute to periapical damage and bone loss in chronic apical periodontitis. Superoxide anion has also been shown to be produced by osteoclasts and involved in bone resorption. Furthermore, superoxide anion may react with a precursor in plasma to generate a factor that is chemotactic for neutrophils. In addition to production by host cells, bacteria can also produce superoxide anion. Production of superoxide by a clinical isolate of a Streptococcus spp. strain was lytic for erythrocytes. Extracellular superoxide production has been reported to be a common trait in strains of E. faecalis [91].

Mynczykowski et al. [92] reported that the surgical treatment leads to a normalization of $\mathrm{O}_{2-}$ and $\mathrm{H}_{2} \mathrm{O}_{2}$ production by circulating polymorphonuclear neutrophils, giving these results as an additional proof of recovery of normal neutrophil function after the elimination of local inflammation by surgical treatment in patients with chronic periapical granuloma.

The arrangement of one atom of nitrogen and one of oxygen in the molecule of nitric oxide leaves an unpaired electron, which makes the molecule a highly reactive free radical. NO is synthesized by a complex family of enzymes, called NO synthases (NOS). There are three NOS: NOS1, NOS2 and NOS3. NOS1 and NOS3 are constitutive, and NOS2 is an inducible, calcium-independent isoform, also called iNOS. Unlike NOS1 and NOS3, induction of NOS2 results in continuous production of NO [93]. The iNOS has been shown to produce a large amount of NO with a stimulation of bacterial LPS and inflammatory cytokines such as IFN- $\gamma$, IL-1 $\beta$ or TNF $\alpha$. Endothelial cells, macrophages, lymphocytes and fibroblasts in periapical lesions demonstrated the production of iNOS with the association of these cytokines [94-96]. The production of iNOS by PMNs was also investigated, but relatively low reactivity was shown [94].

It is suggested that NO plays a pivotal role in regulating inflammatory reaction in apical lesions with the association of cytokines. However, more detailed mechanisms of how NO is related to periapical lesions are unknown. Hama et al. [96] suggested that vascular endothelial cadherin produced by endothelial cells could be regulated by iNOS producing cells in periapical granulomas and may play a pivotal role in vascular permeability. Fukada et al. [97] found that iNOS deficiency is associated with an imbalance in the bone-resorptive modulators RANK, SDF- $1 \alpha /$ CXCL12, and OPG.

\section{CONCLUSIONS}

Apical periodontitis is one of the most common 
endodontic diseases, which endodontists and general practitioners face daily in their practice. It's a very complex pathology with the multiple factors involved. The abundance and interactions of various inflammatory and anti-inflammatory molecules can influence and alter the state and progression of the disease. Therefore, periapical inflammatory response offers a model, suited for the study of many facets of pathogenesis, biocompatibility of different materials to periapical tissues and development of novel treatment methods, based on the regulation of cytokines expression.

\section{ACKNOWLEDGMENTS AND DISCLOSURE STATEMENTS}

The authors declare that they have no conflict of interests.

\section{REFERENCES}

1. Stashenko P, Teles R, D’Souza R. Periapical inflammatory responses and their modulation. Crit Rev Oral Biol Med. 1998;9(4):498-521. Review. [Medline: 9825224] [doi: 10.1177/10454411980090040701]

2. Nair PN. Pathogenesis of apical periodontitis and the causes of endodontic failures. Crit Rev Oral Biol Med. 2004 Nov 1;15(6):348-81. Review. [Medline: 15574679$]$ [doi: 10.1177/154411130401500604]

3. Marton IJ, Kiss C. Characterization of inflammatory cell infiltrate in dental periapical lesions. Int Endod J. 1993 Mar;26(2):131-6. [Medline: 8330936] [doi: 10.1111/j.1365-2591.1993.tb00555.x]

4. Liapatas S, Nakou M, Rontogianni D. Inflammatory infiltrate of chronic periradicular lesions: an immunohistochemical study. Int Endod J. 2003 Jul;36(7):464-71. [Medline: 12823701] [doi: 10.1046/j.1365-2591.2003.00627.x]

5. Gazivoda D, Dzopalic T, Bozic B, Tatomirovic Z, Brkic Z, Colic M. Production of proinflammatory and immunoregulatory cytokines by inflammatory cells from periapical lesions in culture. J Oral Pathol Med. 2009 Aug;38(7):605-11. Epub 2009 May 7. [Medline: 19453841] [doi: 10.1111/j.1600-0714.2009.00788.x]

6. Márton IJ, Kiss C. Protective and destructive immune reactions in apical periodontitis. Oral Microbiol Immunol. 2000 Jun;15(3):139-50. Review. [Medline: 11154396] [doi: 10.1034/j.1399-302x.2000.150301.x]

7. Metzger Z. Macrophages in periapical lesions. Endod Dent Traumatol. 2000 Feb;16(1):1-8. [Medline: 11202850] [doi: 10.1034/j.1600-9657.2000.016001001.x]

8. Rossi D, Zlotnik A. The biology of chemokines and their receptors. Annu Rev Immunol. 2000;18:217-42. [Medline: 10837058 ] [doi: 10.1146/annurev.immunol.18.1.217]

9. Menzies-Gow A, Ying S, Sabroe I, Stubbs VL, Soler D, Williams TJ, Kay AB. Eotaxin (CCL11) and eotaxin-2 (CCL24) induce recruitment of eosinophils, basophils, neutrophils, and macrophages as well as features of early- and late-phase allergic reactions following cutaneous injection in human atopic and nonatopic volunteers. J Immunol. 2002 Sep 1;169(5):2712-8 [Medline: $\underline{12193745]}$ [ [FREE Full Text]

10. Kebschull M, Demmer R, Behle JH, Pollreisz A, Heidemann J, Belusko PB, Celenti R, Pavlidis P, Papapanou PN. Granulocyte chemotactic protein 2 (gcp-2/cxcl6) complements interleukin-8 in periodontal disease. J Periodontal Res. 2009 Aug;44(4):465-71. Epub 2008 Oct 7. [Medline: 18842116] [doi: 10.1111/j.1600-0765.2008.01134.x] [FREE Full Text]

11. Radics T, Kiss C, Tar I, Márton IJ. Interleukin-6 and granulocyte-macrophage colony-stimulating factor in apical periodontitis: correlation with clinical and histologic findings of the involved teeth. Oral Microbiol Immunol. 2003 Feb;18(1):9-13. [Medline: 12588453] [doi: 10.1034/j.1399-302X.2003.180102.x]

12. Marçal JR, Samuel RO, Fernandes D, de Araujo MS, Napimoga MH, Pereira SA, Clemente-Napimoga JT, Alves PM, Mattar R, Rodrigues V Jr, Rodrigues DB. T-helper cell type 17/regulatory T-cell immunoregulatory balance in human radicular cysts and periapical granulomas. J Endod. 2010 Jun;36(6):995-9. [Medline: 20478453] [doi: 10.1016/i.joen.2010.03.020]

13. Silva TA, Lara VS, Silva JS, Garlet GP, Butler WT, Cunha FQ. Dentin sialoprotein and phosphoprotein induce neutrophil recruitment: a mechanism dependent on IL-1beta, TNF-beta, and CXC chemokines. CalcifTissue Int. 2004 Jun;74(6):532-41. [Medline: 15354861] [doi: 10.1007/s00223-003-0159-5]

14. Torabinejad M, Cotti E, Jung T. Concentrations of leukotriene B4 in symptomatic and asymptomatic periapical lesions. J Endod. 1992 May;18(5):205-8. [Medline: 1328456] [doi: 10.1016/S0099-2399(06)81261-6]

15. Silva TA, Garlet GP, Fukada SY, Silva JS, Cunha FQ. Chemokines in oral inflammatory diseases: apical periodontitis and periodontal disease. J Dent Res. 2007 Apr;86(4):306-19. [Medline: 17384024] [doi: 10.1177/154405910708600403]

16. Marton IJ, Rot A, Schwarzinger E, Szakáll S, Radics T, Vályi-Nagy I, Kiss C. Differential in situ distribution of interleukin-8, monocyte chemoattractant protein-1 and Rantes in human chronic periapical granuloma. Oral Microbiol Immunol. $2000 \mathrm{Feb}$;15(1):63-5. [Medline: 11155167] [doi: 10.1034/j.1399-302x.2000.150111.x]

17. Lukić A, Vojvodic D, Majstorović I, Colić M. Production of interleukin-8 in vitro by mononuclear cells isolated from human periapical lesions. Oral Microbiol Immunol. 2006 Oct;21(5):296-300. [Medline: 16922928] [doi: 10.1111/j.1399-302X.2006.00293.x] 
18. Yang LC, Huang FM, Lin CS, Liu CM, Lai CC, Chang YC. Induction of interleukin-8 gene expression by black-pigmented Bacteroides in human pulp fibroblasts and osteoblasts. Int Endod J. 2003 Nov;36(11):774-9. [Medline: 14641442] [doi: 10.1046/j.1365-2591.2003.00740.x]

19. Patel T, Park SH, Lin LM, Chiappelli F, Huang GT. Substance P induces interleukin- 8 secretion from human dental pulp cells. Oral Surg Oral Med Oral Pathol Oral Radiol Endod. 2003 Oct;96(4):478-85. [Medline: 14561975] [doi: 10.1016/S1079-2104(03)00036-2]

20. Park SH, Hsiao GY, Huang GT. Role of substance $P$ and calcitonin gene-related peptide in the regulation of interleukin- 8 and monocyte chemotactic protein-1 expression in human dental pulp. Int Endod J. 2004 Mar;37(3):185-92. [Medline: 15009408] [doi: 10.1111/j.0143-2885.2004.00782.x]

21. Bendre MS, Montague DC, Peery T, Akel NS, Gaddy D, Suva LJ. Interleukin-8 stimulation of osteoclastogenesis and bone resorption is a mechanism for the increased osteolysis of metastatic bone disease. Bone. 2003 Jul;33(1):28-37. [Medline: 12919697] [doi: 10.1016/S8756-3282(03)00086-3]

22. Shimauchi H, Takayama S, Narikawa-Kiji M, Shimabukuro Y, Okada H. Production of interleukin-8 and nitric oxide in human periapical lesions. J Endod. 2001 Dec;27(12):749-52. [Medline: 11771582] [doi: 10.1097/00004770-200112000-00009]

23. Van Damme J, Wuyts A, Froyen G, Van Coillie E, Struyf S, Billiau A, Proost P, Wang JM, Opdenakker G. Granulocyte chemotactic protein-2 and related CXC chemokines: from gene regulation to receptor usage. J Leukoc Biol. 1997 Nov;62(5):563-9. Review. [Medline: 9365109] [FREE Full Text]

24. Miller GA, DeMayo T, Hutter JW. Production of interleukin-1 by polymorphonuclear leukocytes resident in periradicular tissue. J Endod. 1996 Jul;22(7):346-51. [Medline: 8935058] [doi: 10.1016/S0099-2399(96)80215-9]

25. Stashenko P, Wang CY, Tani-Ishii N, Yu SM. Pathogenesis of induced rat periapical lesions. Oral Surg Oral Med Oral Pathol. 1994 Oct;78(4):494-502. Review. [Medline: 7800381] [doi: 10.1016/0030-4220(94)90044-2]

26. Bando Y, Henderson B, Meghji S, Poole S, Harris M. Immunocytochemical localization of inflammatory cytokines and vascular adhesion receptors in radicular cysts. J Oral Pathol Med. 1993 May;22(5):221-7. [Medline: 7686227] [doi: 10.1111/j.1600-0714.1993.tb01060.x]

27. Takahashi K, Kubo T, Arai Y, Kitajima I, Takigawa M, Imanishi J, Hirasawa Y. Hydrostatic pressure induces expression of interleukin 6 and tumour necrosis factor alpha mRNAs in a chondrocyte-like cell line. Ann Rheum Dis. 1998 Apr;57(4):231-6. [Medline: 9709180] [doi: 10.1136/ard.57.4.231] [FREE Full Text]

28. Huang GT, Do M, Wingard M, Park JS, Chugal N. Effect of interleukin-6 deficiency on the formation of periapical lesions after pulp exposure in mice. Oral Surg Oral Med Oral Pathol Oral Radiol Endod. 2001 Jul;92(1):83-8. [Medline: 11458250$]$ [doi: $10.1067 /$ moe.2001.115025]

29. Kobayashi Y. The role of chemokines in neutrophil biology. Front Biosci. 2008;13:2400-7. [Medline: 17981721] [doi: $10.2741 / 2853]$

30. Lundy FT, Linden GJ. Neuropeptides and neurogenic mechanisms in oral and periodontal inflammation. Crit Rev Oral Biol Med. 2004 Jan 1;15(2):82-98. [Medline: 15059944] [doi: 10.1177/154411130401500203] [FREE Full Text]

31. Kabashima H, Nagata K, Maeda K, Iijima T. Involvement of substance P, mast cells, TNF-alpha and ICAM-1 in the infiltration of inflammatory cells in human periapical granulomas. J Oral Pathol Med. 2002 Mar;31(3):175-80. [Medline: 11903825] [doi: 10.1034/j.1600-0714.2002.310309.x]

32. Takahashi K, Poole I, Kinane DF. Detection of interleukin-1 beta mRNA-expressing cells in human gingival crevicular fluid by in situ hybridization. Arch Oral Biol. 1995 Oct;40(10):941-7. [Medline: 8526804] [doi: 10.1016/0003-9969(95)00057-V]

33. KoHJ,Lim SS. Production of macrophage inflammatory protein(MIP)-1alpha and MIP-1beta by human polymorphonuclear neutrophils stimulated with Porphyromonas endodontalis lipopolysaccharide. J Endod. 2002 Nov;28(11):754-7. [Medline: 12470018] [doi: 10.1097/00004770-200211000-00002]

34. Tuncer LI, Alaçam T, Oral B. Substance P expression is elevated in inflamed human periradicular tissue. J Endod. 2004 May;30(5):329-32. [Medline: 15107644] [doi: 10.1097/00004770-200405000-00006]

35. Silva TA, Garlet GP, Lara VS, Martins W, Silva JS, Cunha FQ. Differential expression of chemokines and chemokine receptors in inflammatory periapical diseases. Oral Microbiol Immunol. 2005 Oct;20(5):310-6. [Medline: 16101967] [doi: 10.1111/j.1399-302X.2005.00232.x]

36. Dezerega A, Osorio C, Mardones J, Mundi V, Dutzan N, Franco M, Gamonal J, Oyarzún A, Overall CM, Hernández M. Monocyte chemotactic protein-3: possible involvement in apical periodontitis chemotaxis. Int Endod J. 2010 Oct;43(10):902-8. Epub 2010 Jul 15. [Medline: 20646081] [doi: 10.1111/j.1365-2591.2010.01764.x]

37. Polentarutti N, Introna M, Sozzani S, Mancinelli R, Mantovani G, Mantovani A. Expression of monocyte chemotactic protein-3 in human monocytes and endothelial cells. Eur Cytokine Netw. 1997 Sep;8(3):271-4. [Medline: 9346360] [FREE Full Text]

38. Dezerega A, Pozo P, Hernández M, Oyarzún A, Rivera O, Dutzan N, Gutiérrez-Fernández A, Overall CM, Garrido M, Alcota M, Ortiz E, Gamonal J. Chemokine monocyte chemoattractant protein-3 in progressive periodontal lesions in patients with chronic periodontitis. J Periodontol. 2010 Feb;81(2):267-76. [Medline: 20151806] [doi: 10.1902/jop.2009.090406] 
39. Jäger A, Kuchroo VK. Effector and regulatory T-cell subsets in autoimmunity and tissue inflammation. Scand J Immunol. 2010 Sep;72(3):173-84. Review. [Medline: 20696013] [doi: 10.1111/j.1365-3083.2010.02432.x] [FREE Full Text]

40. Danin J, Linder LE, Lundqvist G, Andersson L. Tumor necrosis factor-alpha and transforming growth factorbeta1 in chronic periapical lesions. Oral Surg Oral Med Oral Pathol Oral Radiol Endod. 2000 Oct;90(4):514-7. [Medline: 11027390] [doi: 10.1067/moe.2000.108958]

41. Teixeira-Salum TB, Rodrigues DB, Gervásio AM, Souza CJ, Rodrigues V Jr, Loyola AM. Distinct Th1, Th2 and Treg cytokines balance in chronic periapical granulomas and radicular cysts. J Oral Pathol Med. 2010 Mar;39(3):250-6. Epub 2010 Jan 21. [Medline: 20102461] [doi: 10.1111/j.1600-0714.2009.00863.x]

42. Colic M, Gazivoda D, Vasilijic S, Vucevic D, Lukic A. Production of IL-10 and IL-12 by antigen-presenting cells in periapical lesions. J Oral Pathol Med. 2010 Oct;39(9):690-6. Epub 2010 Aug 31. [Medline: 20819132] [doi: 10.1111/j.1600-0714.2010.00925.x]

43. Sasaki H, Balto K, Kawashima N, Eastcott J, Hoshino K, Akira S, Stashenko P. Gamma interferon (IFNgamma) and IFN-gamma-inducing cytokines interleukin-12 (IL-12) and IL-18 do not augment infectionstimulated bone resorption in vivo. Clin Diagn Lab Immunol. 2004 Jan;11(1):106-10. [Medline: 14715554] [doi: 10.1128/CDLI.11.1.106-110.2004] [FREE Full Text]

44. Ataoğlu T, Ungör M, Serpek B, Haliloğlu S, Ataoğlu H, Ari H. Interleukin-1beta and tumour necrosis factor-alpha levels in periapical exudates. Int Endod J. 2002 Feb;35(2):181-5. [Medline: 11843974] [doi: 10.1046/j.1365-2591.2002.00467.x]

45. Prso IB, Kocjan W, Simić H, Brumini G, Pezelj-Ribarić S, Borcić J, Ferreri S, Karlović IM. Tumor necrosis factoralpha and interleukin 6 in human periapical lesions. Mediators Inflamm. 2007;2007:38210. Epub 2006 Dec 27. [Medline: 17497030] [FREE Full Text]

46. Stashenko P, Obernesser MS, Dewhirst FE. Effect of immune cytokines on bone. Immunol Invest. 1989 JanMay;18(1-4):239-49. [Medline: 2659511] [doi: 10.3109/08820138909112240]

47. Hong CY, Lin SK, Kok SH, Cheng SJ, Lee MS, Wang TM, Chen CS, Lin LD, Wang JS. The role of lipopolysaccharide in infectious bone resorption of periapical lesion. J Oral Pathol Med. 2004 Mar;33(3):162-9. [Medline: 15128058] [doi: 10.1111/j.0904-2512.2004.00045.x]

48. Kaneko T, Okiji T, Kaneko R, Nör JE, Suda H. Antigen-presenting cells in human radicular granulomas. J Dent Res. 2008 Jun;87(6):553-7. [Medline: 18502964] [doi: 10.1177/154405910808700617]

49. Desai SV, Love RM, Rich AM, Seymour GJ. Antigen recognition and presentation in periapical tissues: a role for TLR expressing cells? Int Endod J. 2011 Feb;44(2):87-99. [Medline: 21083574] [doi: 10.1111/j.1365-2591.2010.01817.x]

50. Vernal R, Dezerega A, Dutzan N, Chaparro A, León R, Chandóa S, Silva A, Gamonal J. RANKL in human periapical granuloma: possible involvement in periapical bone destruction. Oral Dis. 2006 May;12(3):283-9. [Medline: 16700737] [doi: 10.1111/j.1601-0825.2005.01191.x]

51. Ørstavik D, Pitt-Ford TR, editors. Essential endodontology. 2nd ed. Oxford: Blackwell Munksgaard; 2008. p. 48- 9.

52. Fukada SY, Silva TA, Garlet GP, Rosa AL, da Silva JS, Cunha FQ. Factors involved in the Thelper type 1 and type 2 cell commitment and osteoclast regulation in inflammatory apical diseases. Oral Microbiol Immunol. 2009 Feb;24(1):25-31. [Medline: 19121066] [doi: 10.1111/j.1399-302X.2008.00469.x]

53. Kapp JA, Bucy RP. CD8+ suppressor T cells resurrected. Hum Immunol. 2008 Nov;69(11):715-20. Epub 2008 Sep 24. [Medline: 18817830] [doi: 10.1016/j.humimm.2008.07.018]

54. Takeichi O, Hama S, Iwata K, Ito K. Confocal immunolocalization of VE-cadherin- and CXC chemokine-expressing endothelial cells in periapical granulomas. Int Endod J. 2008 May;41(5):401-7. Epub 2008 Feb 20. [Medline: 18298575] [doi: 10.1111/j.1365-2591.2007.01369.x]

55. Ihan Hren N, Ihan A. T lymphocyte activation and cytokine expression in periapical granulomas and radicular cysts. Arch Oral Biol. 2009 Feb;54(2):156-61. Epub 2008 Nov 5. [Medline: 18990362] [doi: 10.1016/j.archoralbio.2008.09.014]

56. de Sá AR, Pimenta FJ, Dutra WO, Gomez RS. Immunolocalization of interleukin 4, interleukin 6, and lymphotoxin alpha in dental granulomas. Oral Surg Oral Med Oral Pathol Oral Radiol Endod. 2003 Sep;96(3):356-60. [Medline: 12973294] [doi: 10.1016/S1079-2104(03)00067-2]

57. Kabashima H, Nagata K, Maeda K, Iijima T. Presence of IFN-gamma and IL-4 in human periapical granulation tissues and regeneration tissues. Cytokine. 2001 Jun 7;14(5):289-93. [Medline: 11444909] [doi: 10.1006/cyto.2001.0879]

58. Colić M, Vasilijić S, Gazivoda D, Vucević D, Marjanović M, Lukić A. Interleukin-17 plays a role in exacerbation of inflammation within chronic periapical lesions. Eur J Oral Sci. 2007 Aug;115(4):315-20. [Medline: 17697172] [doi: 10.1111/j.1600-0722.2007.00460.x]

59. Kopitar AN, Ihan Hren N, Ihan A. Commensal oral bacteria antigens prime human dendritic cells to induce Th1, Th2 or Treg differentiation. Oral Microbiol Immunol. 2006 Feb;21(1):1-5. [Medline: 16390334] [doi: 10.1111/j.1399-302X.2005.00237.x]

60. Alshwaimi E, Purcell P, Kawai T, Sasaki H, Oukka M, Campos-Neto A, Stashenko P. Regulatory T cells in mouse periapical lesions. J Endod. 2009 Sep;35(9):1229-33. [Medline: 19720221] [doi: 10.1016/j.joen.2009.06.006] [FREE Full Text]

61. Kawashima N, Okiji T, Kosaka T, Suda H. Kinetics of macrophages and lymphoid cells during the development of experimentally induced periapical lesions in rat molars: a quantitative immunohistochemical study. J Endod. 1996 Jun;22(6):311-6. [Medline: 8934992] [doi: 10.1016/S0099-2399(96)80266-4] 
62. Wright LM, Maloney W, Yu X, Kindle L, Collin-Osdoby P, Osdoby P. . Stromal cell-derived factor-1 binding to its chemokine receptor CXCR4 on precursor cells promotes the chemotactic recruitment, development and survival of human osteoclasts. Bone. 2005 May;36(5):840-53. [Medline: 15794931] [doi: 10.1016/j.bone.2005.01.021]

63. Havens AM, Chiu E, Taba M, Wang J, Shiozawa Y, Jung Y, Taichman LS, D’Silva NJ, Gopalakrishnan R, Wang C, Giannobile WV, Taichman RS. Stromal-derived factor-1alpha (CXCL12) levels increase in periodontal disease. J Periodontol. 2008 May;79(5):845-53. [Medline: 18454663] [doi: 10.1902/jop.2008.070514] [FREE Full Text]

64. Yu X, Huang Y, Collin-Osdoby P, Osdoby P. CCR1 chemokines promote the chemotactic recruitment, RANKL development, and motility of osteoclasts and are induced by inflammatory cytokines in osteoblasts. J Bone Miner Res. 2004 Dec;19(12):2065-77. Epub 2004 Sep 20. [Medline: 15537451] [doi: 10.1359/jbmr.040910]

65. Novak H, Müller A, Harrer N, Günther C, Carballido JM, Woisetschläger M. CCL23 expression is induced by IL-4 in a STAT6-dependent fashion. J Immunol. 2007 Apr;178(7):4335-41. [Medline: 17371990] [FREE Full Text]

66. Zhang C, Yang L, Peng B. Critical role of NFATc1 in periapical lesions. Int Endod J. 2010 Feb;43(2):109-14. [Medline: 20078699] [doi: 10.1111/j.1365-2591.2009.01649.x]

67. Wong BR, Josien R, Choi Y. TRANCE is a TNF family member that regulates dendritic cell and osteoclast function. $\mathrm{J}$ Leukoc Biol. 1999 Jun;65(6):715-24. [Medline: 10380891] [FREE Full Text]

68. Menezes R, Bramante CM, da Silva Paiva KB, Letra A, Carneiro E, Fernando Zambuzzi W, Granjeiro JM. Receptor activator NFkappaB-ligand and osteoprotegerin protein expression in human periapical cysts and granulomas. Oral Surg Oral Med Oral Pathol Oral Radiol Endod. 2006 Sep;102(3):404-9. Epub 2006 Apr 21. [Medline: 16920551] [doi: 10.1016/j.tripleo.2005.10.054]

69. Takayanagi H, Kim S, Koga T, Nishina H, Isshiki M, Yoshida H, Saiura A, Isobe M, Yokochi T, Inoue J, Wagner EF, Mak TW, Kodama T, Taniguchi T. Induction and activation of the transcription factor NFATc1 (NFAT2) integrate RANKL signaling in terminal differentiation of osteoclasts. Dev Cell. 2002 Dec;3(6):889-901. [Medline: 12479813] [doi: 10.1016/S1534-5807(02)00369-6]

70. Haynes DR, Crotti TN, Potter AE, Loric M, Atkins GJ, Howie DW, Findlay DM. The osteoclastogenic molecules RANKL and RANK are associated with periprosthetic osteolysis. J Bone Joint Surg Br. 2001 Aug;83(6):902-11. Review. [Medline: 11521937] [doi: 10.1302/0301-620X.83B6.10905]

71. Chen SC, Huang FM, Lee SS, Li MZ, Chang YC. The upregulation of receptor activator NF-kappaB ligand expression by interleukin-1alpha and Porphyromonas endodontalis in human osteoblastic cells. Int Endod J. 2009 Apr;42(4):375-80. [Medline: 19298221] [doi: 10.1111/j.1365-2591.2008.01539.x]

72. Kawashima N, Suzuki N, Yang G, Ohi C, Okuhara S, Nakano-Kawanishi H, Suda H. Kinetics of RANKL, RANK and OPG expressions in experimentally induced rat periapical lesions. Oral Surg Oral Med Oral Pathol Oral Radiol Endod. 2007 May;103(5):707-11. Epub 2007 Feb 28. [Medline: 17336108] [doi: 10.1016/j.tripleo.2006.11.036]

73. Hughes FJ, Turner W, Belibasakis G, Martuscelli G. Effects of growth factors and cytokines on osteoblast differentiation. Periodontol 2000. 2006;41:48-72. [Medline: 16686926] [doi: 10.1111/j.1600-0757.2006.00161.x]

74. Tsuji M, Yamasaki M, Amano K, Matsui H, Morimoto T, Nakamura H. Histochemical localization of neutral proteases released during development of rat periradicular lesion. Arch Oral Biol. 2009 Dec;54(12):1128-35. [Medline: 19913217] [doi: 10.1016/j.archoralbio.2009.10.003]

75. Buzoglu HD, Unal H, Ulger C, Mert S, Kücükyildirim S, Er N. The zymographic evaluation of gelatinase (MMP-2 and -9) levels in acute and chronic periapical abscesses. Oral Surg Oral Med Oral Pathol Oral Radiol Endod. 2009 Nov;108(5):e121-6.[Medline: 19836706] [doi: 10.1016/j.tripleo.2009.07.014]

76. Tjäderhane L, Hotakainen T, Kinnunen S, Ahonen M, Salo T. The effect of chemical inhibition of matrix metalloproteinases on the size of experimentally induced apical periodontitis. Int Endod J. 2007 Apr;40(4):282-9. [Medline: 17298412] [doi: $10.1111 / \mathrm{j} .0143-2885.2007 .01223 . x]$

77. Leonardi R, Caltabiano R, Loreto C. Collagenase-3 (MMP-13) is expressed in periapical lesions: an immunohistochemical study. Int Endod J. 2005 May;38(5):297-301. [Medline: 15876293] [doi: 10.1111/j.1365-2591.2005.00943.x]

78. Lin SK, Chiang CP, Hong CY, Lin CP, Lan WH, Hsieh CC, Kuo MY. Immunolocalization of interstitial collagenase (MMP1) and tissue inhibitor of metalloproteinases-1 (TIMP-1) in radicular cysts. J Oral Pathol Med. 1997 Nov;26(10):458-63. [Medline: 9416577] [doi: 10.1111/j.1600-0714.1997.tb00016.x]

79. Lin SK, Kok SH, Kuo MY, Wang TJ, Wang JT, Yeh FT, Hsiao M, Lan WH, Hong CY. Sequential expressions of MMP-1, TIMP-1, IL-6, and COX-2 genes in induced periapical lesions in rats. Eur J Oral Sci. 2002 Jun;110(3):246-53. [Medline: 12120711] [doi: 10.1034/j.1600-0447.2002.11227.x]

80. Wahlgren J, Salo T, Teronen O, Luoto H, Sorsa T, Tjäderhane L. Matrix metalloproteinase-8 (MMP-8) in pulpal and periapical inflammation and periapical root-canal exudates. Int Endod J. 2002 Nov;35(11):897-904. [Medline: 12453017] [doi: $10.1046 / \mathrm{j} .1365-2591.2002 .00587 . x]$

81. Reynaud af Geijersstam A, Sorsa T, Stackelberg S, Tervahartiala T, Haapasalo M. Effect of E. faecalis on the release of serine proteases elastase and cathepsin G, and collagenase-2 (MMP-8) by human polymorphonuclear leukocytes (PMNs). Int Endod J. 2005 Sep;38(9):667-77. [Medline: 16104981] [doi: 10.1111/j.1365-2591.2005.01011.x]

82. Khasigov PZ, Podobed OV, Ktzoeva SA, Gatagonova TM, Grachev SV, Shishkin SS, Berezov TT. Matrix metalloproteinases of normal human tissues. Biochemistry (Mosc). 2001 Feb;66(2):130-40. Review. [Medline: 11255119] [doi: 10.1023/A:1002879128392] 
83. Chaudhary AK, Singh M, Bharti AC, Asotra K, Sundaram S, Mehrotra R. Genetic polymorphisms of matrix metalloproteinases and their inhibitors in potentially malignant and malignant lesions of the head and neck. J Biomed Sci. 2010;17:10. [Medline: 20152059] [doi: 10.1186/1423-0127-17-10] [FREE Full Text]

84. Gusman H, Santana RB, Zehnder M. Matrix metalloproteinase levels and gelatinolytic activity in clinically healthy and inflamed human dental pulps. Eur J Oral Sci. 2002 Oct;110(5):353-7. [Medline: 12664465] [doi: $10.1034 / \mathrm{j} .1600-0722.2002 .21347 . \mathrm{x}]$

85. Shin SJ, Lee JI, Baek SH, Lim SS. Tissue levels of matrix metalloproteinases in pulps and periapical lesions. J Endod. 2002 Apr;28(4):313-5. [Medline: 12043871] [doi: 10.1097/00004770-200204000-00013]

86. Belmar MJ, Pabst C, Martínez B, Hernández M. Gelatinolytic activity in gingival crevicular fluid from teeth with periapical lesions. Oral Surg Oral Med Oral Pathol Oral Radiol Endod. 2008 Jun;105(6):801-6. [Medline: 18439854] [doi: 10.1016/j.tripleo.2007.12.002]

87. Panagakos FS, O’Boskey JF, Rodriguez E. Regulation of pulp cell matrix metalloproteinase production by cytokines and lipopolysaccharides. J Endod. 1996 Jul;22(7):358-61. [Medline: 8935061] [doi: 10.1016/S0099-2399(96)80218-4]

88. Ueda L, Matsushima K. Stimulation of plasminogen activator activity and matrix metalloproteinases of human dental pulp-derived cells by tumor necrosis factor-alpha. J Endod. 2001 Mar;27(3):175-9. [Medline: 11487146] [doi: 10.1097/00004770-200103000-00008]

89. Alptekin NO, Ari H, Ataoglu T, Haliloglu S, Alptekin T, Serpek B. Neutrophil elastase levels in periapical exudates of symptomatic and asymptomatic teeth. J Endod. 2005 May;31(5):350-3. [Medline: 15851927] [doi: 10.1097/01.don.0000140567.25382.cd]

90. Alptekin NO, Ari H, Haliloglu S, Alptekin T, Serpek B, Ataoglu T. The effect of endodontic therapy on periapical exudate neutrophil elastase and prostaglandin-E2 levels. J Endod. 2005 Nov;31(11):791-5. [Medline: 16249720] [doi: 10.1097/01.don.0000158010.43884.59]

91. Kayaoglu G, Ørstavik D. Virulence factors of Enterococcus faecalis: relationship to endodontic disease. Crit Rev Oral Biol Med. 2004 Sep 1;15(5):308-20. Review. [Medline: 15470268] [doi: 10.1177/154411130401500506]

92. Minczykowski A, Woszczyk M, Szczepanik A, Lewandowski L, Wysocki H. Hydrogen peroxide and superoxide anion production by polymorphonuclear neutrophils in patients with chronic periapical granuloma, before and after surgical treatment. Clin Oral Investig. 2001 Mar;5(1):6-10. [Medline: 11355101] [doi: 10.1007/s007840000095]

93. Brennan PA, Thomas GJ, Langdon JD. The role of nitric oxide in oral diseases. Arch Oral Biol. 2003 Feb;48(2):93-100. Review. [Medline: 12642227] [doi: 10.1016/S0003-9969(02)00183-8]

94. Takeichi O, Saito I, Okamoto Y, Tsurumachi T, Saito T. Cytokine regulation on the synthesis of nitric oxide in vivo by chronically infected human polymorphonuclear leucocytes. Immunology. 1998 Feb;93(2):275-80. [Medline: 9616379] [doi: 10.1046/j.1365-2567.1998.00413.x] [FREE Full Text]

95. Takeichi O, Hayashi M, Tsurumachi T, Tomita T, Ogihara H, Ogiso B, Saito T. Inducible nitric oxide synthase activity by interferon-gamma-producing cells in human radicular cysts. Int Endod J. 1999 Mar;32(2):124-30. [Medline: 10371908] [doi: 10.1046/j.1365-2591.1999.00203.x]

96. Hama S, Takeichi O, Hayashi M, Komiyama K, Ito K. Co-production of vascular endothelial cadherin and inducible nitric oxide synthase by endothelial cells in periapical granuloma. Int Endod J. 2006 Mar;39(3):179-84. [Medline: 16507070] [doi: $10.1111 / \mathrm{j} .1365-2591.2006 .01068 . x$ ]

97. Fukada SY, Silva TA, Saconato IF, Garlet GP, Avila-Campos MJ, Silva JS, Cunha FQ. iNOS-derived nitric oxide modulates infection-stimulated bone loss. J Dent Res. 2008 Dec;87(12):1155-9. [Medline: 19029085] [doi: 10.1177/154405910808701207]

\section{To cite this article:}

Graunaite I, Lodiene G, Maciulskiene V. Pathogenesis of Apical Periodontitis: a Literature Review.

J Oral Maxillofac Res 2011;2(4):e1

URL: http://www.ejomr.org/JOMR/archives/2011/4/e1/v2n4e1ht.pdf

doi: $10.5037 /$ jomr.2011.2401

Copyright (C) Graunaite I, Lodiene G, Maciulskiene V. Accepted for publication in the JOURNAL OF ORAL \& MAXILLOFACIAL RESEARCH (http://www.ejomr.org), 3 September 2011.

This is an open-access article, first published in the JOURNAL OF ORAL \& MAXILLOFACIAL RESEARCH, distributed under the terms of the Creative Commons Attribution-Noncommercial-No Derivative Works 3.0 Unported License, which permits unrestricted non-commercial use, distribution, and reproduction in any medium, provided the original work and is properly cited. The copyright, license information and link to the original publication on (http://www.ejomr.org) must be included. 